\title{
PRODUKTIVITAS KERJA KARYAWAN DITINJAU DARI MOTIVASI, DISIPLIN KERJA DAN LINGKUNGAN KERJA PADA PT. ISKANDAR INDAH PRINTING TEXTILE SURAKARTA
}

\author{
${ }^{1}$ Khairunisa Nur Baiti, ${ }^{2}$ Djumali, ${ }^{3}$ Eny Kustiyah \\ Fakultas Ekonomi Manajemen, Universitas Islam Batik Surakarta \\ khairunisabaiti@gmail.com
}

\begin{abstract}
This research aims to determine the influence of simultaneous motivation, work discipline and work environment on employee productivity PT. Iskandar Indah Printing Textile Surakarta, to determine the influence of motivation on productivity of employee at PT. Iskandar Indah Printing Textile Surakarta, to deternime the influence of work discipline on productivity of employee at PT. Iskandar Indah Printing Textile Surakarta, to determine the influence of work environment on productivity of employee at PT. Iskandar Indah Printing Textile Surakarta. The population in this research was 975 employee. Sampling of 100 respondents. Hyphothesis testing using multiple linier regression. Simultaneously motivation, work discipline and work environment and positive and significant effect on productivity of employee at PT. Iskandar Indah Printing Textile Surakarta with value $F_{\text {test }}>F t_{\text {able }}(27,102)>2,70$ significantly 0,000 < 0,05 . Partially the motivation $\left(X_{1}\right)$ positive and significant effect on productivity of employee with $t_{\text {test }}(1,641)>t_{\text {table }}(1,984)$ and significant value 0,104 $>0,05$. The variable work discipline $\left(X_{2}\right)$ positive and significant effect on productivity of employee with $t_{\text {test }}(8,830)>t_{\text {table }}(1,9840$ and significant value 0,000 $<0,05$. The variable work environment $\left(X_{3}\right)$ positive and significant effect on productivity of employee a with $t_{\text {test }}(0,001)<t_{\text {table }}(1,984)$ and significant value 0,999 $>0,05$.
\end{abstract}

Keywords : motivation, work disipline, work environment and work productivity

\section{PENDAHULUAN}

Perkembangan di era globalisasi saat ini, masalah sumber daya manusia menjadi tumpuan bagi perusahaan yang utamanya menjaga produktivitas kerja karyawan itu sendiri. Segala tuntutan perusahaan dalam mempertahankan dan mengelola sumber daya manusia yang berkualitas semakin mendesak oleh adanya dinamika lingkungan yang berubah. (Haryo \& W, 2018). Dikatakan produktif apabila sumber daya tersebut memiliki produktivitas kerja yang tinggi serta dapat mencapai sasaran atau target yang telah ditentukan dan dapat bertanggung jawab menyelesaikan tugas dengan tepat waktu. (Putu, Claudia, \& Suana, 2018)

Produktivitas kerja karyawan sebagai tolak ukur bagi setiap perusahaan dalam menjalankan kegiatan usahanya baik dari segi kualitas maupun kuantitas produk. Seperti halnya di persaingan dagang saat ini dimana perusahaan harus mengupayakan mutu dan kesejahteraan karyawan yang menjadi daya saing perusahaan lain. Perusahaan tidak hanya memiliki modal besar saja untuk mencapai tujuannya tetapi perusahaan perlu memperhatikan faktor produksi lain diantaranya alam, tenaga kerja dan keahlian dimana faktor itu tidak dapat berdiri sendiri 
melainkan harus saling mendukung untuk mencapai tujuan secara efektif dan efisien. (Wirawan, Haris, \& Suwena, 2019).

Perusahaan dalam meningkatkan efisiensi dan efektifitas menjadi modal bagi seorang manajemen. Tujuan utama perusahaan adalah memperoleh laba dan menjadi yang terbaik dalam memenuhi kebutuhan konsumen. Diantara tujuan tersebut perusahaan dituntut untuk selalu berproduktif menghasilkan produk yang bermutu, berkualitas dan mempunyai daya guna berkelanjutan. (Saleh \& Utomo, 2018). Beberapa faktor yang dapat mempengaruhi tinggi rendahnya produktivitas kerja karyawan diantaranya adalah motivasi, disiplin kerja dari diri seorang dan didukung oleh lingkungan kerja yang memadai. Pemanfaatan sumber daya manusia pada sektor industri yang berkualitas menjadi kunci keberhasilan pencapaian tujuan perusahaan. (Van de Lande, et al, 2016). Dengan demikian, seorang karyawan yang memiliki motivasi, disiplin kerja yang tinggi serta mendapat dukungan lingkungan kerja yang nyaman dan baik akan mampu melakukan pekerjaanya sesuai target produktivitas kerja yang maksimal.

Dotulong \& Assagaf (2015) motivasi kerja menjadi peranan yang dibutuhkan bagi setiap organisasi, umumnya produktivitas kerja para karyawan akan dipengaruhi oleh produktivitas organisasi tersebut. Karenanya motivasi menjadi pendorong bagi karyawan untuk bekerja dan menimbulkan rasa semangat serta kepuasan dalam melaksanakan pekerjaan dengan baik. Seorang karyawan dalam motivasi kerjanya dapat timbul ketika karyawan tersebut mendapat dorongan dari lingkungan keluarga, lingkungan masyarakat ataupun lingkungan saat bekerja bahkan motivasi itu juga dapat timbul dari diri sendiri. Perlu diketahui motivasi kerja dipengaruhi oleh beberapa faktor diantaranya adanya keinginan untuk memenuhi kebutuhan, meningkatkan prestasi kerja dan mencari pengalaman. Banyak sekali keinginan diri sendiri terutama berkaitan dengan gaya hidup seseorang yang termotivasi ingin mempunyai barang seperti orang lain punya. Sebaliknya jika motivasi kerja karyawan yang kurang baik akan mempengaruhi produktivitas dan berdampak buruk bagi perusahaan.

Dahlan (2014) motivasi dapat diartikan sebagai sebuah tindakan dari seorang manajemen dalam meningkatkan jenjang karir melalui prestasi kerja di dalam perusahaan. Menciptakan motivasi tersebut dengan cara memberikan sebuah imbalan baik material maupun non material. Hubungan motivasi erat dengan produktivitas kerja, dimana semakin tinggi tingkat motivasi seseorang maka semakin bersemangat pula menyelesaikan pekerjaan dan hasil lebih cepat dengan kualitas sesuai standar yang ditetapkan.

Upaya meningkatkan produktivitas kerja karyawan setiap perusahaan harus memperhatikan tingkat disiplin kerja. Disiplin kerja merupakan penerapan yang penting bagi suatu perusahaan. Dimana, semua aktivitas kerjanya dikendalikan oleh aturan-aturan yang harus ditaati setiap karyawan sehingga mampu melaksanakan pekerjaan lebih optimal. Dorongan dari perusahaan yang setiap harinya diberlakukan sikap disiplin bagi karyawan memicu untuk lebih giat dan semangat serta menjadi pengaruh besar terhadap produktivitas kerja. Putra (2018) disiplin kerja berawal dari diri kita sendiri yang secara naluri muncul ketika melakukan hal berkaitan dengan sikap siap dan mampu meminimalisir suatu masalah. Hilangnya sikap disiplin akan menurunkan efisiensi dan efektivitas tugas-tugas di perusahaan. Bila disiplin kerja tidak ditegakkan maka tujuan yang hendak dicapai akan tidak dapat berjalan secara efektif dan efisien dalam produktivitas karyawan. 
Disiplin kerja sangatlah diperlukan agar karyawan dapat bertanggung jawab atas pekerjaan yang diberikan kepadanya. Bagi perusahaan dengan disiplin kerja maka akan menjamin kelancaran dalam melaksanakan tugas sehingga memperoleh hasil kerja yang baik sedangkan bagi karyawan dengan disiplin kerja yang tinggi maka karyawan akan memperoleh suasana kerja yang menyenangkan, tepat waktu sesuai dengan rencana sehingga dapat mencegah adanya pemborosan waktu yang digunakan bukan semestinya.

Karyawan memiliki tugas disetiap bagian-bagian unit kerja untuk melaksanakan kegiatan operasionalnya di lingkungan kerja perusahaan. Kemungkinan disaat mereka beraktivitas memiliki pengaruh pada produktivitas kerja. Lingkungan kerja yang kondusif menjadi pendukung produktivitas karyawan, sebaliknya lingkungan yang tidak nyaman maka akan mengganggu konsentrasi bekerja. Masalah yang timbul di lingkungan perusahaan tidak boleh diabaikan oleh perusahaan. Maka dari itu perusahaan mengupayakan untuk memperhatikan lingkungan kerja karyawan. Dalam mendukung produktivitas kerja, faktor lingkungan kerja mempunyai keterkaitan. Menciptakan lingkungan kerja yang nyaman dan kondusif telahir dari kesadaran diri karyawan dan pimpinan di perusahaan. (Ramadon, Syahri \&Yanti Pasmawati., 2017).

Lingkungan kerja yang baik apabila karyawan dalam suatu perusahaan melaksanakan kegiatan operasionalnya dapat berjalan dengan lancar. Meningkatkan produktivitas karyawan agar lebih baik perlu didukung dengan adanya lingkungan kerja yang sehat dan kondusif. Produktivitas karyawan dapat meningkat apabila lingkungan kerja yang ada di sekitar karyawan kondusif, karena dengan lingkungan kerja yang kondusif akan dapat memberikan kelancaran, rasa senang, aman dan keselamatan dalam melaksanakan tugas yang diberikan kepadanya.

PT. Iskandar Indah Printing Textile adalah perusahaaan yang beralamatkan di Jalan Pakel No. 11 Kerten Laweyan Surakarta. Perusahaan ini bergerak dalam bidang tekstil manufaktur yang memproduksi kain yang disebut dengan kain grey yang berbahan baku dari benang, kemudian meningkatkan jenis produksi berupa kain bercorak atau lebih dikenal dengan sebutan batik printing. Bagian produksi di PT. Iskandar Indah Printing Textile dibagi menjadi dua departemen yaitu weaving dan printing.

Perusahaan sangat membutuhkan produktivitas karyawan yang optimal agar mendapat hasil yang maksimal, maka sangatlah penting bagi perusahaan untuk memperhatikan dari segi pemberian motivasi bagi karyawan seperti bonus dan penghargaan. Hal tersebut dilakukan agar karyawan merasa tidak cepat merasa puas sehingga akan lebih meningkatkan produktivitasnya sehingga tercapai tujuan yang diinginkan.

Karyawan di PT. Iskandar Indah Printing Textile yang datang terlambat dan sering izin tidak tepat waktu akan menyebabkan tidak berjalannya dengan baik rencana kegiatan operasionalnya. Maka dari itu perlu adanya sanksi yang tegas bagi karyawan yang melanggar dan agar lebih tertib dalam bekerja di perusahaan. Untuk dapat bekerja dengan maksimal faktor lingkungan kerja seperti penerangan yang memadai, ventilasi udara diruang kerja yang cukup dan tingkat kebisingan yang rendah menjadi daya penggerak karyawan untuk bekerja dengan nyaman. Tidak tersedianya kantin diperusahaan juga merupakan kurangnya fasilitas untuk karyawan. 
Masalah yang terjadi pada perusahaan ini mengenai gejolak naik turun hasil produksi yang dihasilkan tidak sesuai dengan target yang ditetapkan setiap harinya. standar angka yang harus dicapai perharinya maksimal 8.000 potong dengan panjang 2,5 meter kain batik printing. Untuk mencapai hasil target produksi, manajemen melakukan keputusan sistem kerja lembur perharinya. Terjadinya keluar masuk karyawan juga menjadi pengaruh dari produktivitas kerja di perusahaan dikarenakan kurangnya motivasi, disiplin kerja karyawan dan kurangnya lingkungan yang nyaman dari perusahaan tersebut. Oleh karena itu produktivitas kerja sangatlah penting diterapkan di perusahaan ini untuk memenuhi kebutuhan barang yang dihasilkan memiliki kualitas dan konsumen merasa puas.

Berdasarkan uraian diatas maka penulis sangat tertarik untuk melakukan penelitian dengan judul Produktivitas Kerja Ditinjau Dari Motivasi, Disiplin Kerja Dan Lingkungan Kerja Pada PT. Iskandar Indah Printing Textile Surakarta.

\section{LANDASAN TEORI}

\section{Produktivitas Kerja}

Produktivitas merupakan suatu proses dimana sumber daya manusia dapat menghasilkan suatu keluaran dengan ukuran yang produktif. Produktivitas juga dapat diartikan sebagai proses yang memfokuskan perhatian pada keluaran yang dihasilkan oleh sumber daya manusia dengan suatu rasio antara masukan dan keluaran. (Ramadon, Syahri \&Yanti Pasmawati., 2017)

Dahlan (2014) produktivitas merupakan hasil membandingkan peran serta tenaga kerja per satuan waktu dengan hasil yang dicapai. Produktivitas tenaga kerja adalah suatu konsep dimana terjadi adanya keterkaitan antara seorang sumber tenaga kerja dengan hasil satuan waktu, menunjukkan produk yang dibutuhkan lebih tinggi melalui standar yang di tetapkan.

Produktivitas Kerja adalah dimana produk barang maupun jasa yang dihasilkan oleh setiap individu atau kelompok yang menunjukan pertimbangan antara input dan output dengan tindakan kinerja lebih efisien. (Wibowo, 2018). Menurut Handoko (2011:135) faktor-faktor yang mempengaruhi produktivitas kerja adalah : (1) Tingkat pendidikan (2) Keterampilan (3) Disiplin kerja (4) Motivasi (5) Gizi dan Kesehatan (6) Tingkat penghasilan (7) Jaminan sosial (8) Lingkungan dan iklim kerja (9) Hubungan industrial (10) Teknologi (11) Sarana produksi (12) Manajemen (13) Kesempatan berprestasi.

Menurut Sutrisno (2016:102) mengemukakan bahwa Produktivitas kerja adalah rasio dari keseluruhan hasil kerja yang telah ditentukan untuk menghasilkan suatu produk dari tenaga kerja. Untuk mengukur suatu produktivitas kerja karyawan, diperlukan suatu indikator menurut Sutrisno (2016:104-105) sebagai berikut :

1) Kemampuan

Kemampuan karyawan menjadi profesionalime dalam bekerja. Karyawan dibekali keterampilan untuk menjadi daya dalam menyelesaikan tugas-tugas yang diberikan.

2) Meningkatkan hasil yang dicapai

Bertekad meningkatkan hasil yang dicapai. Upaya ini berguna untuk meningkatkan produktiviytas kerja perusahaan dan menambah kuantitas hasil dalam bekerja.

3) Semangat kerja 
Berusaha untuk lebih baik dari kemarin dan meningkatkan kinerja kerja. Semangat mampu membuat karyawan untuk mengevaluasi dari hari sebelumnya.

4) Pengembangan diri

Pengembangan diri senantiasa dilakukan untuk meningkatkan hasil kerja dengan kemampuan diri yang dimiliki. Melalui langkah pengembangan diri seorang karyawan akan menemukan tantangan dan harapan. Tantangan yang terjadi setiap karyawan akan membuat sebuah motivasi untuk bersaing secara sehat. Begitu harapan akan berdampak untuk memiliki keinginan seorang karyawan meningkatkan kemampuan.

5) Mutu

Berusaha meningkatkan mutu yang baik dan berkualitas dari yang sebelumnya. Meningkatkan mutu bermanfaat untuk meningkatkan hasil yang terbaik bagi perusahaan dan pengaruhnya produktivitas perusahaan meningkat.

6) Efisiensi

Membandingkan sumber daya yang digunakan dengan apa yang dicapainya selama berlangsungnya proses kerja.

\section{Motivasi}

Motivasi adalah faktor-faktor yang bersumber dari dalam maupun dari luar diri seseorang muncul ketika melalui proses psikologi. Motivasi kerja mampu membuat seseorang untuk bertanggung jawab dengan pekerjaanya dan memaksimalkan taget yang dicapai. (Saleh \& Utomo, 2018).

Maduka \& Okafor (2014) motivasi sebagai suatu proses, dimulai dengan kebutuhan manusia yang menciptakan kekosongan dalam diri seseorang dengan berupaya untuk mengisi ruang hampa, kekuatan pendorong internal dihasilkan yang memulai dan menopang rantai aksi dan reaksi maka titik itulah vakum juga terisi.

Motivasi kerja juga berperan penting dalam produktivitas karyawan. Motivasi kerja dapat berupa dalam bentuk verbal atau pun non verbal. Motivasi kerja adalah kegiatan yang dapat menimbulkan rasa atau mendorong seorang karyawan untuk bekerja dan memberikan prestasi kerja sesuai dengan visi dan misi perusahaan dimana setiap karyawan melakukan pekerjaan. Motivasi kerja dapat berasal dari lingkungan kerja, lingkungan dimana orang tersebut tinggal dan motivasi kerja dapat timbul dari karyawan itu sendiri. (Haryo \& W, 2018).

Menurut Anhar (2012:110) dalam meningkatkan produktivitas kerja karyawan, terdapat beberapa pokok-pokok motivasi yaitu :

1) Kepuasan kerja.

2) Mengukur potensi pekerjaan yang memberikan kepuasan.

3) Desain pekerjaan yang memotivasi pekerjaan.

4) Faktor sosial dalam motivasi.

5) Pemberian perangsang dan imbalan demi motivasi.

6) Pelatihan.

7) Peluang untuk berkembang (promosi)

8) Motivasi dan kemajuan bisnis. 
Perusahaan dalam memberikan motivasi kepada karyawan disaat bekerja tentunya mempunyai tujuan tertentu. Menurut Istiatin \& Ida (2016:45) ada beberapa tujuan dari motivasi sebagai berikut :

1) Meningkatkan moral dan kepuasan kerja karyawan

2) Meningkatkan produktivitas karyawan

3) Mempertahankan kestabilan karyawan perusahaan

4) Meningkatkan kedisiplinan karyawan

5) Mengefektifkan pengadaan karyawan

6) Menciptakan suasana dan hubungan kerja yang baik

7) Meningkatkan loyalitas, kreatifitas dan partisipasi karyawan

8) Meningkatkan kesejahteraan karyawan

9) Mempertinggi rasa tanggung jawab karyawan terhadap tugas-tugasnya

10) Meningkatkan efisiensi penggunaan alat-alat dan bahan baku

Menurut Sastrohadiwiryo (2013:119) mengemukakan bahwa sikap mental yang dimiliki manusia dan keadaan kejiwaan yang memberikan suatu energi, mengarahkan perilaku dan mendorong kegiatan ke arah pencapaian kebutuhan dan kepuasan serta tidak mengurangi ketidakseimbangan. Adapun indikator-indikator yang dapat digunakan sebagai pengukur motivasi kerja seorang karyawan adalah sebagai berikut :

1) Kinerja (Achievement)

2) Penghargaan (Recognition)

3) Tantangan (Challenge)

4) Tanggung Jawab (Responsibility)

5) Pengembangan (Development)

6) Keterlibatan (Involvement)

7) Kesempatan (Opportunity)

\section{Disiplin Kerja}

Disiplin adalah pengendalian diri, implementasi karyawan reguler dan menunjukkan tingkat keseriusan dalam tim kerja dalam suatu organisasi. Tindakan disipliner menuntut hukuman terhadap karyawan yang gagal memenuhi standar yang ditetapkan. Tindakan disipliner yang efektif berpusat pada perilaku karyawan yang salah, bukan pada karyawan sebagai pribadi pribadi. (Elqadri, Wardoyo, \& -, 2015).

Disiplin merupakan sebuah proses dimana seseorang dapat menumbuhkan rasa untuk meningkatkan dan mempertahankan tujuan yang hendak dicapai melalui sikap patuh dalam menjalankan aturan organisasi. (Saleh \& Utomo, 2018).

Menurut Dermawan (2013:41) mengemukakan bahwa disiplin kerja sebagai suatu sikap atau tingkah laku seseorang yang beperan untuk menjalankan peraturam baik wujud tertulis atau tidak dalam setiap organisasi. Disiplin kerja menurut Sutrisno (2012:89) adalah tingkah laku, perbuatan dan sikap yang sesuai dengan peraturan dari organisasi baik tertulis maupun yang tidak tertulis.

Menurut Mangkunegara (2013:129) terdapat dua bentuk disiplin kerja yaitu disiplin preventif dan disiplin korektif. Disiplin preventif merupakan suatu upaya untuk menggerakkan 
pegawai mengikuti dan mematuhi pedoman kerja, aturan-aturan yang telah digariskan perusahaan. tujuan dasarnya adalah untuk menggerakkan pegawai berdisiplin diri. Dengan cara ini, karyawan dapat memelihara dirinya terhadap peraturan-peraturan perusahaan. Disiplin preventif merupakan suatu sistem yang berhubungan dengan kebutuhan kerja semua bagian sistem yang ada dalam organisasi. Disiplin korektif yaitu suatu upaya dalam menggerakkan pegawai dalam menyatukan suatu peratutan dan mengarahkan untuk tetap mematuhi peraturan sesuai dengan pedoman yang berlaku pada perusahaan.

Menurut Fahmi (2016:75) ada beberapa bentuk tindakan mengenai sanksi yang harus dimiliki oleh seorang karyawan akibat tindakan tidak disiplin atau indisipliner. Berikut bentuk teguran secara umum berbentuk sebagai berikut : (1) Penurunan jabatan (2) Pemindahan posisi (3) Pemutusan Hubungan Kerja (PHK) (4) Termasuk pengaduan terhadap pihak berwajib.

Disiplin kerja menurut Sastrohadiwiryo (2013:291) adalah suatu sikap patuh, taat, menghormati dan mampu menghargai setiap peraturan yang berlaku, baik secara tertulis maupun tidak tertulis serta tidak menghindar dan menerima sanksi jika terjadi pelanggaran dalam menjalankan tugas. Adapun indikator disiplin kerja menurut Sastrohadiwiryo (2013:291) yaitu :

1) Frekuensi kehadiran

2) Tingkat kewaspadaan

3) Ketaatan pada standar kerja

4) Ketaatan pada peraturan kerja

5) Etika kerja.

\section{Lingkungan Kerja}

Abdul \& Awan (2015) lingkungan secara harfiah berarti mengelilingi dan semua hal yang berdampak pada manusia selama hidup secara kolektif dikenal sebagai lingkungan. Lingkungan kerja sebagai tempat dimana orang bekerja bersama-sama yang berguna untuk mencapai sebuah tujuan organisasi.

Lingkungan kerja adalah keseluruhan dari alat perkakas dan bahan yang dihadapi, lingkungan sekitarnya dimana seseorang bekerja, metode kerjanya, serta pengaturan kerjanya baik sebagai perseorangan maupun sebagai kelompok. (Handaru, 2019). Lingkungan kerja didefinisikan oleh sebuah ruang, tata letak fisik, kebisingan, alat-alat, bahan-bahan, dan hubungan rekan sekerja serta kualitas dari semuanya ini yang mempunyai dampak positif yang penting pada kulitas kerja yang dihasilkan. (Tumiwa, Tewal \& Palandeng, 2017).

Goyal \& Singhal (2017) lingkungan kerja berarti segala sesuatu yang ada bagian dari keterlibatan karyawan dengan pekerjaan itu sendiri, seperti hubungan dengan kolega dan atasan, budaya organisasi, ruang untuk pengembangan diri, dan seterusnya. Lingkungan kerja adalah sebuah komponen penting di perusahaan yang harus menjadi perhatian khusus bagi pihak manajemen, lingkungan sangat mempengaruhi produktivitas karena merupakan tempat dimana suatu produk tersebut dihasilkan. Saleh \& Utomo (2018).

Menurut Wijayanto (2012:41) mengemukakan bahwa lingkungan kerja merupakan kumpulan dari individu atau kelompok menjadi internal stakeholder yang dipertegas menjadi bagian dari lingkungan organisasi yang dimana internal stakehoder adalah seorang pemimpim atau manajer yang mempunyai tanggung jawab terhadap kepentingan mereka. 
Dalam pengertian lain lingkungan kerja menurut Sunyoto (2012:43) adalah bagian dari sebuah komponen penting yang berasal dari dalam aktivitas karyawan saat bekerja. Didalam perusahaan faktor lingkungan kerja sangat mempengaruhi produktivitas kerja karyawan. Menurut Sunyoto (2012) faktor-faktor yang mempengaruhi lingkungan kerja meliputi :

1) Hubungan karyawan

Terdapat dua hubungan didalam hubungan karyawan yaitu hubungan antara invidu dan hubungan antara kelompok.

2) Tingkat kebisingan lingkungan kerja

Lingkungan kerja yang tidak nyaman akan mengganggu jalannya aktivitas bekerja. Tingkat kebisingan di lingkungan kerja menjadi faktor ketidaktenangan karyawan dan menjadi pengaruh kurang baik.

3) Peraturan kerja

Peraturan yang dibuat dengan jelas dan baik akan membuat karyawan merasa patuh dan mentaati peraturan yang berlaku serta karyawan dapat menjalankan kinerja dalam mengembangkan karir.

4) Penerangan

Penerangan tidak hanya listrik tetapi termasuk juga pancaran sinar matahari. Kondisi penerangan lingkungan kerja yang cukup dan memungkinkan membuat karyawan nyaman bekerja.

5) Sirkulasi udara

Pengadaan ventilasi yang memadai membuat sirkulasi udara di ruangan menjadi baik.

6) Keamanan

Menimbulkan rasa keamanan dan kenyamanan di lingkungan kerja menjadi dorongan semangat bekerja.

Menurut Sedarmayanti (2011:26) lingkungan kerja terdiri dari lingkungan kerja fisik dan non fisik, lingkungan kerja fisik adalah semua keadaan dari lingkungan sekitar yang berbentuk fisik yang dapat mempengaruhi karyawan baik secara langsung maupun tidak langsung. Sedangkan lingkungan kerja non fisik adalah semua keadaan dari lingkungan sekitar yang berkaitan dengan hubungan kerja karyawan, baik hubungan dengan atasan maupun serekan kerja, ataupun hubungan dengan bawahan. Adapun indikator-indikator lingkungan kerja Sedarmayanti (2011:28), yaitu :

1) Penerangan ditempat kerja

2) Temperatur ditempat kerja

3) Kelembaban udara ditempat kerja

4) Sirkulasi udara ditempat kerja

5) Kebisingan ditempat kerja

6) Getaran mekanis ditempat kerja

7) Bau tidak sedap ditempat kerja

8) Dekorasi ditempat kerja

9) Musik ditempat kerja

10) Keamanan ditempat kerja 


\section{METODOLOGI PENELITIAN}

\section{Jenis penelitian}

Dalam penelitian ini menggunakan jenis penelitian diskriptif dengan pendekatan kuantitatif. Penelitian ini dilakukan bertempat di PT. Iskandar Indah Printing Textile Surakarta yang beralamatkan di Jalan Pakel No. 11 Kerten Surakarta. Penelitian ini berlangsung dari bulan November - Desember 2019.

\section{Populasi dan Sampel}

Populasi adalah suatu wilayah generalisasi yang terdiri dari objek atau subjek yang memiliki kualitas dan spesifikasi tertentu yang diterapkan oleh peneliti untuk dipelajari dan menarik kesimpulan. (Sugiyono, 2016:215). Adapun yang menjadi populasi dalam penelitian ini adalah seluruh karyawan pada PT. Iskandar Indah Printing Textile Surakarta yang berjumlah 975 karyawan. Sampel adalah bagian dari suatu jumlah dan spesifikasi yang dimiliki oleh suatu populasi. (Sugiyono, 2016:215). Dalam penelitian ini pengambilan sampel menggunakan rumus slovin, sampel yang diambil berjumlah 100 responden.

\section{Teknik Sampling}

Teknik pengambilan sampel dilakukan secara Simple Random Sampling yaitu teknik pengambilan sampel yang dilakukan secara acak dengan tidak memperhatikan strata atau tingkatan dalam populasi. (Sugiyono, 2016:81)

\section{Jenis dan Sumber data}

Jenis data yang digunakan dalam penelitian ini adalah data kuantitatif. Sumber data yang digunakan adalah data primer dan data sekunder. Data primer adalah data yang diambil dari objek atau objek penelitian secara langsung oleh peneliti perorangan maupun organisasi. (Wijaya, 2013:19). Data sekunder adalah data yang diambil dari objek penelitian secara tidak langsung, dengan mendapatkan data yang sudah jadi dan kemudian dikumpulkan oleh pihak lain melalui berbagai cara baik secara komersial maupun non komersial. Wijaya (2013:19).

\section{Teknik Pengumpulan Data}

Cara mengumpulkan data yang dilakukan dalam penelitian ini peneliti menggunakan metode sebagai berikut : (1) Observasi sebagai teknik pengumpul data mempunyai ciri yang spesifik bila dibanding dengan teknik lain, observasi tidak terbatas pada orang tetapi juga objekobjek alam yang lain. (Sugiyono, 2016:145). (2) Wawancara Sebagai teknik pengumpulan data apabila peneliti ingin melakukan studi pendahuluan untuk menemukan permasalahan yang harus diteliti, dan juga apabila peneliti ingin mengetahui hal-hal dari responden yang lebih mendalam dan jumlah respondenya sedikit/kecil. (Sugiyono, 2016:137). (3) Kuisioner merupakan teknik pengambilan data yang dilakukan dengan cara memberi seperangkat pertanyaan maupun pernyataan tertulis kepada responden untuk dijawabnya (Sugiyono, 2016:142). (4) Dokumentasi merupakan suatu cara pengumpulan data yang dilakukan dengan menganalisis isi dokumen yang berhubungan dengan masalah yang diteliti. (5) Studi kepustakaan segala usaha yang dilakukan oleh peneliti untuk menghimpun informasi yang relevan dengan topik atau masalah yang akan 
atau sedang diteliti. Metode ini dapat dilakukan dengan cara mencari buku-buku ilmiah, laporan penelitian, buku tahunan, ensiklopedia dan sumber-sumber tertulis maupun elektronik.

\section{Instrumen Penelitian}

Menurut Ghozali (2011:47) Skala yang dipakai dalam penyusunan kuisioner adalah skala ordinal atau sering disebut skala Likert yaitu skala yang berisi lima tingkat preferensi jawaban dengan pilihan sebagai berikut :

1) Alternatif jawaban sangat setuju (SS), diberi skor 5

2) Alternatif jawaban setuju (S), diberi skor 4

3) Alternatif jawaban netral $(\mathrm{N})$, diberi skor 3

4) Alternatif jawaban tidak setuju ( TS), diberi skor 2

5) Alternatif jawaban sangat tidak setuju (STS), diberi skor 1

\section{Metode Analisis}

\section{Uji Validitas dan Reliabilitas}

Ghozali (2011:52) uji validitas digunakan untuk mengukur sah atau tidak validnya suatu kuisioner. Kuisioner dikatakan valid jika pertanyaan atau penyataan pada kuisioner mampu mengungkapkan sesuatu yang akan diukur oleh kuisioner tersebut. Jika instrumen tersebut mengukur apa yang seharusnya diukur. Uji reliabilitas adalah alat untuk mengukur suatu kuisioner yang merupakan indikator dari suatu variabel atau konstruk. Suatu kuisioner dikatakan reliabel atau handal jika pertanyaan adalah konsisten atau stabil dari waktu ke waktu. Ghozali (2011:47). Pengukuran reliabilitas menggunakan cara One Shot atau pengukuran sekali saja yang kemudian hasilnya dibandingkan dengan pertanyaan lainnya. Dengan bantuan SPSS memberikan fasilitas untuk mengukur reliabilitas dangan uji statistik Cronbach Alpha $(\alpha)$. Suatu konstruk atau variabel dikatakan reliabel jika memberikan nilai Cronbach Alpha > 0,70 (Nunnaly, 1994).

\section{Uji Asumsi Klasik}

\section{Uji Normalitas}

Uji normalitas digunakan untuk menguji apakah data sebuah model regresi, variabel independen atau variabel dependen atau keduanya terdistribusi normal atau tidak. (Ghozali, 2011:160).

\section{Uji Multikolinearitas}

Uji Multikolinieritas bertujuan untuk menguji dalam model regresi apakah ditemukan adanya hubungan antar variabel bebas (independen). Dalam multi regresi yang baik seharusnya tidak terjadi hubungsdiantara variabel bebas. Jika variabel bebas saling berhubungan maka variabel-variabel ini tidak orthogona. Untuk mendeteksi ada tidaknya multikolinearitas dalam regresi dapat dilihat dari besarnya nilai tolerance dan lawannya. Jika nilai tolerance value $>0,10$ dan VIF $<10$ maka tidak terjadi multikolinearitas.

\section{Uji Heteroskedastisitas}

Uji ini bertujuan untuk mengukur apakah dalam model regresi terjadi ketidaksamaan variance dan residual suatu pengamatan ke pengamatan lain. Uji heteroskedastisitas dapat dilihat dengan menggunakan grafik plot antara lain prediksi variabel terikat Standardized predicted 
value dengan studentized residual. Jika grafik plot menunjukkan suatu pola titik seperti titik yang bergelombang atau melebar kemudian menyempit, maka dapat disimpulkan bahwa telah terjadi heteroskedastisitas. (Ghozali, 2011:139).

\section{Analisis Data}

\section{Uji Analisis Regresi Linier Berganda}

Untuk mengukur kekuatan asosiasi (hubungan) linier antara dua atau lebih variabel dan mengetahui besarnya pengaruh variabel dependen dengan variabel independen. (Ghozali, 2011:96). Adapun rumus regresi linier berganda sebagai berikut: :

$$
Y=a+b_{1} X_{1}+b_{2} X_{2}+b_{3} X_{3}+e
$$

\section{Uji Signifikansi Simultan (uji F)}

Uji statistik F menunjukkan apakah dari semua variabel independen yang dimasukkannya kedalam model mempunyai pengaruh secara bersama-sama atau simultan terhadap variabel dependen. Hipotesis sering disebut pengujian signifikansi keseluruhan (overall significance) terhadap garis regresi yang ingin menguji apakah $\mathrm{Y}$ secara linier berhubungan dengan ketiga $\mathrm{X}_{1}$, $\mathrm{X}_{2}$ dan $\mathrm{X}_{3}$. Uji hipotesa ini dengan teknik analisis variance ( ANOVA). (Ghozali, 2011:98).

\section{Uji Signifikansi Parameter Individual (uji t)}

Uji t pada dasarnya menunjukkan seberapa jauh pengaruh satu variabel independen terhadap variabel dependen dengan menganggap variabel independen konstan. Ghozali (2011:98).

\section{Uji Koefisien Determinasi $\mathbf{R}^{2}$}

Koefisien determinasi bertujuan untuk mengukur bagaimana kemampuan model dalam menerangkan variasi-variabel dependen. Koefisien determinasi memiki nilai adalah antara nol (0) dan satu (1). Nilai $\mathrm{R}^{2}$ yang dinilai lebih kecil berarti kemampuan variabel-variabel independen dalam menjelaskan variasi variabel dependen sangatlah terbatas. Nilai yang mendekati satu berarti variabel-variabel independen memberikan hampir semua informasi yang dibutuhkan untuk diprediksi variasi variabel dependen. (Ghozali,2011:98).

\section{HASIL DAN PEMBAHASAN}

\section{Hasil penelitian}

\section{Uji Validitas}

Adapun hasil uji validitas dari masing-masing variabel sebagai berikut:

Tabel IV.5 Validitas Variabel Produktivitas Kerja (Y)

\begin{tabular}{|c|c|c|c|}
\hline No Item & $\mathrm{r}_{\text {hitung }}$ & $\mathrm{r}_{\text {tabel }}$ & Keterangan \\
\hline 1 & 0,701 & 0,1654 & Valid \\
2 & 0,639 & 0,1654 & Valid \\
3 & 0,726 & 0,1654 & Valid \\
4 & 0,691 & 0,1654 & Valid \\
5 & 0,695 & 0,1654 & Valid \\
\hline
\end{tabular}

Sumber : Data Primer diolah tahun 2019 
Berdasarkan dari hasil tabel diatas menunjukkan bahwa 5 item pernyataan mengenai produktivitas kerja $(\mathrm{Y})$ yang diajukan kepada responden dinyatakan valid karena nilai $\mathbf{r}_{\text {hitung }}>$ $\mathrm{r}_{\text {tabel}}$.

Tabel IV.6 Validitas Variabel Motivasi $\left(\mathbf{X}_{1}\right)$

\begin{tabular}{|c|c|c|c|}
\hline No Item & $\mathrm{r}_{\text {hitung }}$ & $\mathrm{r}_{\text {tabel }}$ & Keterangan \\
\hline 1 & 0,747 & 0,1654 & Valid \\
2 & 0,744 & 0,1654 & Valid \\
3 & 0,692 & 0,1654 & Valid \\
4 & 0,573 & 0,1654 & Valid \\
5 & 0,686 & 0,4438 & Valid \\
\hline
\end{tabular}

Sumber : Data Primer diolah tahun 2019

Berdasarkan dari tabel diatas menunjukkan bahwa 5 item pernyataan mengenai motivasi $\left(\mathrm{X}_{1}\right)$ yang diajukan kepada responden dinyatakan valid karena nilai $r_{\text {hitung }}>r_{\text {tabel }}$.

Tabel IV.7 Validitas Variabel Disiplin Kerja $\left(\mathbf{X}_{2}\right)$

\begin{tabular}{|c|c|c|c|}
\hline No Item & $\mathrm{r}_{\text {hitung }}$ & $\mathrm{r}_{\text {tabel }}$ & Keterangan \\
\hline 1 & 0,716 & 0,1654 & Valid \\
2 & 0,668 & 0,1654 & Valid \\
3 & 0,684 & 0,1654 & Valid \\
4 & 0,720 & 0,1654 & Valid \\
5 & 0,792 & 0,1654 & Valid \\
\hline
\end{tabular}

Sumber : Data Primer diolah tahun 2019

Berdasarkan dari data diatas menunjukkan bahwa 5 item pernyataan mengenai disiplin kerja $\left(\mathrm{X}_{2}\right)$ yang diajukan kepada responden dinyatakan valid karena $r_{\text {hitung }}>r_{\text {tabel }}$.

Tabel IV.8 Validitas Variabel Lingkungan Kerja $\left(\mathbf{X}_{3}\right)$

\begin{tabular}{|c|c|c|c|}
\hline No Item & $\mathrm{r}_{\text {hitung }}$ & $\mathrm{r}_{\text {tabel }}$ & Keterangan \\
\hline 1 & 0,678 & 0,1654 & Valid \\
2 & 0,787 & 0,1654 & Valid \\
3 & 0,710 & 0,1654 & Valid \\
4 & 0,696 & 0,1654 & Valid \\
5 & 0,645 & 0,1654 & Valid \\
\hline
\end{tabular}

\section{Sumber : Data Primer diolah tahun 2019}

Berdasarkan dari data diatas menunjukka bahwa 5 item pernyataan mengenai lingkungan kerja $\left(\mathrm{X}_{3}\right)$ yang diajukan kepada responden dinyatakan valid karena $r_{\text {hitung }}>r_{\text {tabel. }}$. 


\section{Uji Reliabilitas}

\section{Tabel IV.9 Hasil Uji Reliabilitas}

\begin{tabular}{|c|c|c|c|}
\hline Variabel & Alpha & $\begin{array}{c}\text { Standar } \\
\text { Reliabilitas }\end{array}$ & Keterangan \\
\hline Produktivitas Kerja & 0,717 & 0,70 & Reliabel \\
\hline Motivasi & 0,723 & 0,70 & Reliabel \\
\hline Disiplin Kerja & 0,747 & 0,70 & Reliabel \\
\hline Lingkungan Kerja & 0,743 & 0,70 & Reliabel \\
\hline
\end{tabular}

Sumber : Data Primer diolah tahun 2019

Berdasarkan dari data tabel diatas menunjukkan bahwa semua item pernyataan mengenai produktivitas kerja, motivasi, disiplin kerja dan lingkungan kerja dinyatakan reliabel karena semua variabel mempunyai nilai Cronbach Alpha $>0,70$.

\section{Uji Normalitas}

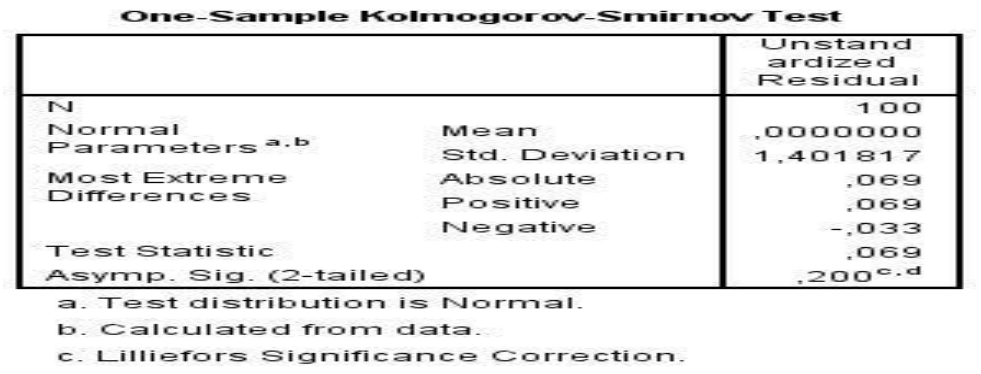

Sumber : Data Primer diolah tahun 2019

Tabel IV.10 Hasil Uji Normalitas

Berdasarkan data tabel IV.10, nilai Asymp. Sig (2-tailed) adalah 0,200 lebih besar dari 0,05 yang berarti data tersebut terdistribusi normal

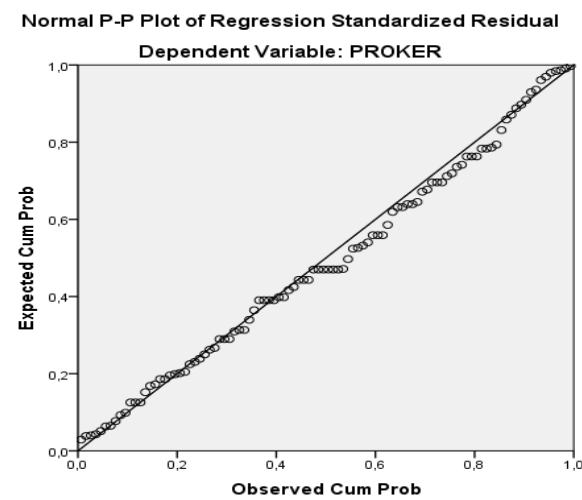

Sumber : Data primer diolah tahun 2019

Gambar IV.2 
Berdasarkan hasil grafik diatas membuktikan bahwa titik-titik tersebut menyebar disekitar garis diagonal dan mengikuti arah garis diagonal menunjukkan pola tersebut terdistribusi normal. Hal ini yang digunakan dalam penelitian ini adalah normal.

\section{Uji Multikolinearitas}

Tabel IV.11 Hasil Uji Multikolinearitas

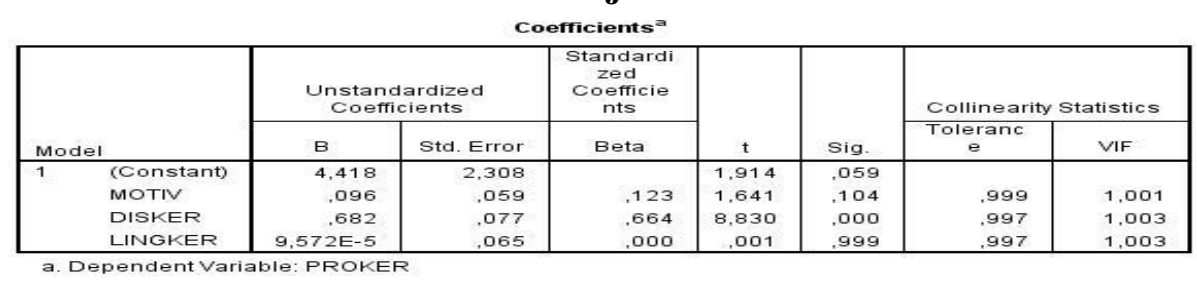

Berdasarkan tabel IV.11 diatas menunjukkan bahwa masing-masing variabel nilai VIF kurang dari 10, sedangkan hasil nilai tolerance diatas 0,1 . Dengan demikian dapat dinyatakan model regresi ini tidak terjadi multikolinearitas.

\section{Uji Heteroskedastisitas}

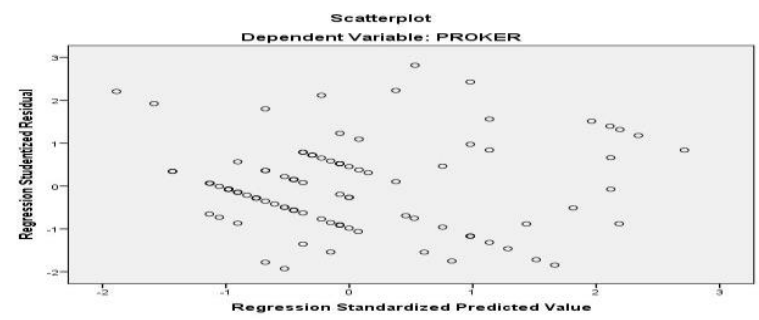

Sumber : Data primer diolah tahun 2019

Gambar IV.3

Berdasarkan gambar IV.3 membuktikan bahwa titik-titik tersebut berada diatas dan dibawah nilai 0 . Hal ini menunjukkan bahwa model regresi ini tidak terjadi adanya heteroskedastisitas.

\section{Analisis Regresi Linier Berganda}

Tabel IV.12 Hasil Analisis Regresi Linier Berganda

\begin{tabular}{|c|c|c|c|c|c|c|}
\hline \multicolumn{7}{|c|}{ Coefficients $^{a}$} \\
\hline & & \multicolumn{2}{|c|}{$\begin{array}{l}\text { Unstandardized } \\
\text { Coefficients }\end{array}$} & $\begin{array}{l}\text { Standardi } \\
\text { zed } \\
\text { Coefficie } \\
\text { nts }\end{array}$ & & \\
\hline \multicolumn{2}{|c|}{ Model } & B & Std. Error & Beta & $t$ & Sig. \\
\hline \multirow[t]{4}{*}{1} & (Constant) & 4,418 & 2,308 & & 1,914 & .059 \\
\hline & MOTIV &, 096 & .059 & .123 & 1,641 & .104 \\
\hline & DISKER & .682 & .077 & .664 & 8,830 & .000 \\
\hline & LINGKER & $9,572 \mathrm{E}-5$ & .065 & .000 & .001 & 999 \\
\hline
\end{tabular}

\section{Sumber : Data Primer diolah tahun 2019}

Berdasarkan data tabel IV.12 dapat dirumuskan model regresi linier berganda dalam penelitian ini sebagai berikut :

$$
\mathrm{Y}=4,418+0,096 \mathrm{X} 1+0,682 \mathrm{X} 2+9,572 \mathrm{X} 3+\mathrm{e}
$$

Nilai konstanta $(\alpha)$ sebesar 4,418 artinya apabila variabel independen yaitu motivasi $\left(\mathrm{X}_{1}\right)$, disiplin kerja $\left(\mathrm{X}_{2}\right)$ dan lingkungan kerja $\left(\mathrm{X}_{3}\right)$ nilainya $0(\mathrm{nol})$, maka variabel produktivitas kerja 
akan berada pada angka 4,418. Koefisien variabel motivasi $\left(b_{1}\right)$ dari perhitungan regresi linier nilai coefficients $(b)=0,096$. Hal ini berarti jika motivasi meningkat sebesar satu-satuan sementara variabel lain tetap maka produktivitas kerja karyawan akan meningkat sebesar 0,096. Koefisien variabel disiplin kerja $\left(b_{2}\right)$ dari perhitungan regresi linier nilai coeficients $(b)=0,682$. Hal ini berarti jika variabel disiplin kerja meningkat sebesar satu-satuan dan variabel lainnya tetap maka produktivitas kerja karyawan meningkat sebesar 0,682. Keofisien variabel lingkungan kerja $\left(b_{3}\right)$ dari perhitungan regresi linier nilai coefisients $(b)=9,572$. Hal ini berarti jika variabel lingkungan kerja meningkat sebesar satu-satuan dan variabel lainnya tetap maka produktivitas kerja karyawan meningkat sebesar 9,572.

\section{Uji Signifikansi Simultan (Uji F)}

\section{Tabel IV.13 Hasil Uji F}

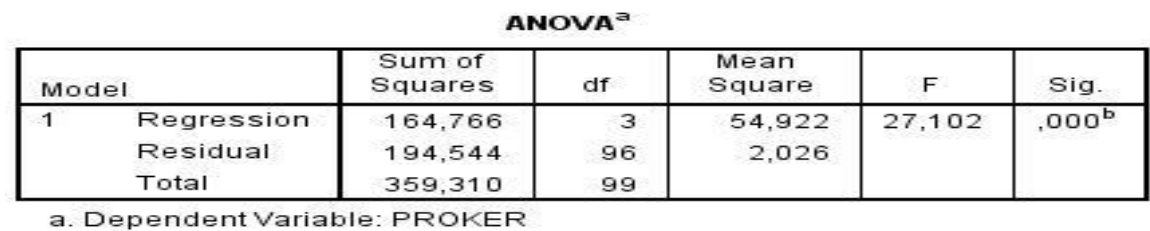

b. Predictors: (Constant), LINGKER, MOTIV, DISKER

\section{Sumber : Data Primer diolah tahun 2019}

Berdasarkan tabel IV.13 menunjukkan bahwa nilai uji $f_{\text {hitung }}(27,102)>f_{\text {tabel }}(2,70)$ dengan signifikansi $0,000<0,05$, maka dapat simpulkan Ho ditolak, artinya variabel motivasi, disiplin kerja dan lingkungan kerja secara simultan berpengaruh positif terhadap produktivitas kerja pada PT. Iskandar Indah Printing Textile Surakarta.

\section{Uji Signifikansi Parsial (Uji t)}

Tabel IV.14 Hasil Uji t

coefficients ${ }^{a}$

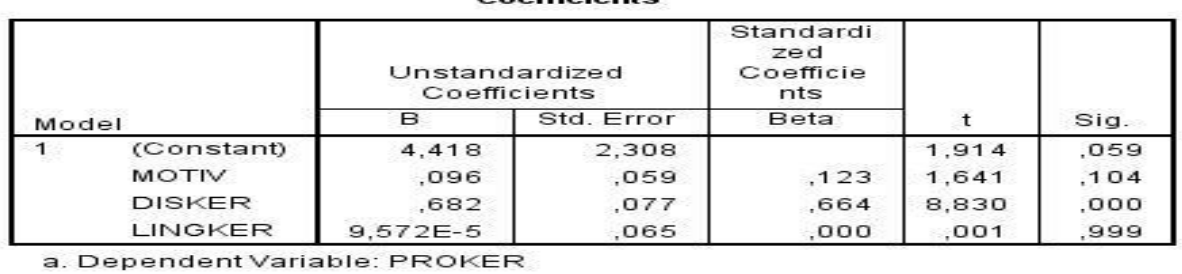

Sumber : Data Primer diolah tahun 2019

Berdasarkan tabel IV.14 menunjukkan bahwa hasil uji t motivasi $\left(\mathrm{X}_{1}\right)$ nilai $\mathrm{t}_{\text {hitung }}(1,641)$ $<t_{\text {tabel }}(1,984)$ dengan signifikansi 0,104 > 0,05 artinya Ho ditolak, maka motivasi berpengaruh positif dan signifikan terhadap produktivitas kerja. Disiplin kerja $\left(\mathrm{X}_{2}\right)$ nilai $t_{\text {hitung }}(8,830)>t_{\text {tabel }}$ $(1,984)$ dengan signifikansi $0,000<0,05$ artinya Ho ditolak, maka disiplin kerja berpengaruh positif dan signifikan terhadap produktivitas kerja. Lingkungan kerja $\left(\mathrm{X}_{3}\right)$ nilai $\mathrm{t}_{\text {hitung }}(0,001)<$ $\mathrm{t}_{\text {tabel }}(1,984)$ dengan signifikansi $0,999>0,05$ artinya Ho ditolak, maka lingkungan kerja berpengaruh positif dan signifikan terhadap produktivitas kerja. 


\section{Uji Koefisien Determinasi $\left(\mathbf{R}^{2}\right)$}

Tabel IV.15 Hasil Uji Koefisien Determinasi $\left(\mathbf{R}^{2}\right)$

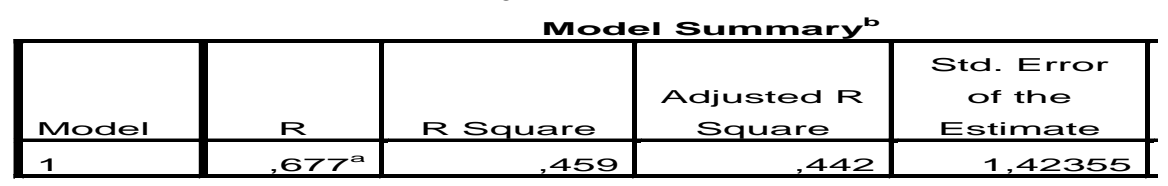

a. Predictors: (Constant), LINGKER, MOTIV, DISKER

b. Dependent Variable: PROKER

\section{Sumber : Data Primer diolah tahun 2019}

Berdasarkan hasil tabel IV.15 menunjukkan bahwa koefisien determinasi (Adjusted $R$ Square) sebesar 0,442 atau 44,2\%. Hal ini dapat disimpulkan bahwa 44,2\% variabel produktivitas kerja dapat dijelaskan oleh variabel motivasi, disiplin kerja dan lingkungan kerja., sedangkan sisanya sebesar $55,8 \%$.

\section{PEMBAHASAN}

\section{Hipotesis pertama $\left(\mathrm{H}_{1}\right)$}

Dari tabel IV.13 terlihat bahwa dari nilai uji $F$ menunjukkan nilai $F_{\text {hitung }}>F_{\text {tabel }}(27,102)$ $>(2,70)$ dengan signifikansi 0,000 < 0,05, dengan demikian Ho ditolak dan Ha diterima. Jadi dapat disimpulkan bahwa variabel motivasi, disiplin kerja dan lingkungan kerja secara simultan berpengaruh positif terhadap produktivitas kerja pada PT. Iskandar Indah Printing Textile Surakarta.

\section{Hipotesis kedua $\left(\mathbf{H}_{2}\right)$}

Dari tabel IV.14 terlihat bahwa hasil pengujian hipotesis variabel motivasi $\left(\mathrm{X}_{1}\right)$ nilai $\mathrm{t}_{\text {hitung }}(1,641)<\mathrm{t}_{\text {tabel }}(1,984)$ dengan signifikansi 0,104 > 0,05 artinya Ho ditolak dan Ha dierima, maka secara parsial motivasi memiliki pengaruh yang positif dan signifikan terhadap produktivitas kerja pada PT. Iskandar Indah Printing Textile Surakarta.

\section{Hipotesis ketiga $\left(\mathbf{H}_{3}\right)$}

Dari tabel IV.14 terlihat bahwa hasil pengujian hipotesis variabel disiplin kerja (X2) nilai $t_{\text {hitung }}(8,830)>t_{\text {tabel }}(1,984)$ dengan signifikansi $0,000<0,05$ artinya Ho ditolak, maka secara parsial disiplin kerja memiliki pengaruh yang positif dan signifikan terhadap produktivitas kerja pada PT. Iskandar Indah Printing Textile Surakarta.

\section{Hipotesis keempat $\left(\mathbf{H}_{4}\right)$}

Dari tabel IV.14 terlihat bahwa hasil pengujian hipotesis variabel lingkungan kerja $\left(\mathrm{X}_{3}\right)$ nilai $t_{\text {hitung }}(0,001)<t_{\text {tabel }}(1,984)$ dengan signifikansi $0,999>0,05$ artinya Ho ditolak, maka secara parsial lingkungan kerja memiliki pengaruh yang positif dan signifikan terhadap produktivitas kerja pada PT. Iskandar Indah Printing Textile Surakarta.

\section{Uji Determinasi $\left(\mathbf{R}^{2}\right)$}

Dari perhitungan regresi dapat diketahui bahwa koefisien determinasinya $\left(\mathrm{R}^{2}\right)$ yang diperoleh sebesar 0,442 atau 44,2\%. Hal ini dapat disimpulkan bahwa 44,2\% variabel produktivitas kerja dapat dijelaskan oleh variabel motivasi, disiplin kerja dan lingkungan kerja., sedangkan sisanya sebesar 55,8\% dijelaskan oleh variabel lainnya yang tidak dimasukkan dalam model regresi. 


\section{KESIMPULAN DAN SARAN}

\section{Kesimpulan}

Dari hasil penelitian dapat disimpulkan sebagai berikut :

a. Secara simultan variabel motivasi, disiplin kerja dan lingkungan kerja berpengaruh positif dan signifikan terhadap produktivitas kerja pada PT. Iskandar Indah Printing Textile Surakarta.

b. Motivasi berpengaruh positif dan signifikan terhadap produktivitas kerja pada PT. Iskandar Indah Printing Textile Surakarta. Dengan pemberian motivasi baik secara internal maupun internal akan meningkatkan produktivitas kerja karyawan.

c. Disiplin kerja berpengaruh positif dan signifikan terhadap produktivitas kerja pada PT. Iskandar Indah Printing Textile Surakarta. Disiplin kerja yang baik akan meningkatkan produktivitas kerja karyawan.

d. Lingkungan kerja berpengaruh positif dan signifikan terhadap produktivitas kerja pada PT. Iskandar Indah Printing Textile Surakarta. Dengan didukung lingkungan kerja yang bersih, aman dan kondusif akan meningkatkan produktivitas kerja karyawan dan memberikan kenyamanan dalam bekerja.

\section{Saran}

Peneliti menyarankan beberapa hal sebagai berikut :

a. Diharapkan pihak perusahaan harus meningkatkan pemberian motivasi kepada seluruh karyawan pada PT. Iskandar Indah Printing Textile Surakarta dengan cara memberikan bonus, penghargaan dan hadiah setiap akhir bulan maupun akhir tahun sebagaimana agar produktivitas kerja lebih meningkat.

b. Diharapkan pihak perusahaan harus meningkatkan kesadaran untuk disiplin kerja dengan cara disiplin waktu dalam hal kehadiran karyawan maupun menyelesaikan pekerjaan, agar pelaksanaan rencana kegiatan dapat berjalan dengan tepat waktu.

c. Diharapkan pihak perusahaan harus menciptakan kondisi di lingkungan kerja yang aman, bersih dan kondusif, agar karyawan merasakan kenyamanan dalam meningkatkan produktivitas kerja yang maksimal

\section{DAFTAR PUSTAKA}

Abdul, P., \& Awan, G. 2015. Impact of working environment on employee's productivity: A case study of Banks and Insurance Companies in Pakistan. 7(1), 329-346.

Anhar, D. 2012. Pengaruh Motivasi Terhadap Peningkatan Produktivitas Kerja, Edisi Revisi. Jakarta: Bumi Aksara.

DAHLAN. 2014. Pengaruh Motivasi Terhadap Peningkatan Produktivitas Kerja Karyawan Pada Pt. Bank Rakyat Indonesia (Persero). Jurnal Salewangang, 8(1),2026.Retrievedfromhttp://ojsstimyapim.com/index.php/JS/article/view/33 
Dermawan. D. 2013. Prinsip-prinsip Perilaku Organisasi. Bandung: Media Grafika.

Dotulong, L., \& Assagaf, S. 2015. Pengaruh Disiplin, Motivasi Dan Semangat Kerja Terhadap Produktivitas Kerja Pegawai Dinas Pendapatan Daerah Kota Manado. Jurnal Riset Ekonomi, Manajemen, Bisnis Dan Akuntansi, 3(2), 639-649.

Elqadri, Z. M., Wardoyo, D. T. W., \& -, P. 2015. The Influence of Motivation and Discipline Work against Employee Work Productivity Tona'an Markets. Review of European Studies, 7(12), 59-66. https://doi.org/10.5539/res.v7n12p59

Fahmi, I. 2016. Manajemen Kepemimpinan Teori \& Aplikasi. Bandung: CV Alfabeta.

Ghozali, I. 2011. Aplikasi Analisis Multivarite dengan IBM SPSS 19. Semarang: Universitas Diponegoro.

Goyal, S., \& Singhal, S. 2017. Impact of Work Environment on Employee Satisfaction: an Empirical Study. OORJA - International Journal of Management \& IT, 15(2), 40-47. Retrieved from http://search.ebscohost.com/login.aspx?direct=true \&db=bth\&AN=128869928\&site=ehostlive

Handaru, A. W. 2019. Produktivitas Kerja Karyawan ( Kasus Pt Artolite Indah Mediatama). $10(2), 386-404$.

Handoko, T. H. 2011. Manajemen Personalia dan Sumber Daya Manusia, Edisi Kedua, Cetakan Kesebelas. Yogyakarta: BPFE.

Haryo, B. D., \& W, H. D. 2018. Pengaruh Pelatihan Kerja, Motivasi Kerja dan Lingkungan Kerja terhadap Produktivitas Kerja KaryawaPT. Metec Semarang. Diponegoro Journal of Management, 1-6.

Informasi, P. T., Kerja, L., Kompetensi, D. A. N., \& Palandeng, I. D. 2017. Pengaruh Teknologi Informasi, Lingkungan Kerja Dan Kompetensi Terhadap Produktivitas Karyawan (Study Pada Kantor Pusat Bank Sulutgo). Jurnal EMBA: Jurnal Riset Ekonomi, Manajemen, Bisnis Dan Akuntansi, 5(3), 3895-3904.

Istiatin \& Ida Aryati PW. 2016. Manajemen Sumber Daya Manusia. Surakarta: Arial Black Printing Graphic Design.

Maduka, C. E., \& Okafor, O. 2014. Effect of Motivation on Employee Productivity: A Study of Manufacturing Companies in Nnewi. International Journal of Managerial Studies and Research, 2(7), 137-147. Retrieved from www.arcjournals.org

Mangkunegara, A. P. 2013. Manajemen Sumber Daya Manusia Perusahaan. Bandung: PT. Remaja Rosdakarya.

Putra, A. 2018. Pengaruh Motivasi Dan Penerapan Disiplin Kerja Terhadap Produktivitas Kerja 
Pegawai Pada Rumah Sakit Ibu Kartini Kisaran. Journal of Science and Social Research, 2(August), 153-158.

Putu, N., Claudia, C., \& Suana, I. W. 2018. DENPASAR AGUNG Fakultas Ekonomi dan Bisnis Universitas Udayana, Bali, Indonesia Keberhasilan organisasi perusahaan tergantung pada produktivitas karyawannya sehingga produktivitas menjadi pertimbangan sangat penting dalam mencapai tujuan organisasi ters. 7(10), 5379-5406.

Ramadon, Syahri., Yanti Pasmawati., C. D. K. 2017. Pengaruh Lingkungan Kerja Fisik Terhadap Produktivitas Kerja. Universitas Bina Darma, 3(12), 1-12.

Saleh, A. R., \& Utomo, H. 2018. Pengaruh Disiplin Kerja, Motivasi Kerja Terhadap Produktivitas Kerja Karyawan Bagian Produksi di PT Inko Java Semarang. Among Makarti, 11(21), 28-50.

Sastrohadiwiryo, B. 2013. Manajemen Tenaga Kerja Indonesia (Pendekatan Adminitratif dan Operasional). Jakarta: Bumi Aksara.

Sugiyono. 2016. Metodologi Penelitian Kuantitatif, Kualitatif dan R\&D. Bandung: CV Alfabeta.

Sunyoto, D. 2012. Manajemen Sumber Daya Manusia. Yogyakarta: PT. Caps.

Sutrisno, E. 2016. Manajemen Sumber Daya Manusia (Cetakan ke-8). Jakarta: Kencana.

van de Lande, R., Maurice-Stam, H., Van Vuurden, D., Grootenhuis, M., \& Schouten-van Meeteren, A. 2016. Qos-50Adaptive Behaviour in Children With Low Grade Glioma. Neuro-Oncology, 18(suppl 3), iii156.2-iii156. https://doi.org/10.1093/neuonc/now081.50

Wibowo, F. P. 2018. Pengaruh Komunikasi, Konflik, Stres Kerja, dan Lingkungan Kerja terhadap Produktivitas Karyawan. Jurnal Manajemen Sumber Daya Manusia, 12(2), 211228. https://doi.org/10.1017/CBO9781107415324.004

Wijaya, T. (2013). Metodologi Penelitian Ekonomi dan Bisnis Teori dan Praktik. Jakarta: Graha Ilmu.

Wirawan, P. J., Haris, I. A., \& Suwena, K. R. 2019. Pengaruh Disiplin Kerja Terhadap Produktivitas Kerja Karyawan Bagian Produksi Pada Pt. Tirta Mumbul Jaya Abadi Tahun 2016. Jurnal Pendidikan Ekonomi Undiksha, 10(1), 305. https://doi.org/10.23887/jjpe.v10i1.20149 